Research Article

\title{
The Implementation of Character Education in Kindergarten
}

\author{
Mifti Mufidah*, Ririn Rachmayanie Jamain \\ Master Program of Early Childhood Teacher Education, Universitas Lambung Mangkurat, Banjarmasin \\ 70123, Indonesian
}

Article history:

Submission December 2019

Revised July 2020

Accepted July 2020

*Corresponding author:

E-mail: mifti18.mufid@gmail.com

\begin{abstract}
Implementation of character education in early childhood is vital since it has a significant influence on all aspects of life. It uses a qualitative approach with multi-site design and data collection techniques through interviews, observation. The data were analyzed descriptively began with reduction, presentation, and concluding. The results showed that the character values include religious/love of God, care for the environment or the universe and its contents, honest, tolerance, discipline, hard work and unyielding, creative, independent, patriotism/love of peace and unity, responsibility, social care/philanthropic, like helping, and cooperation, democratic, curiosity, enthusiasm, respect for achievement, friendly and communicative, fond of reading, respectful and polite, confident, fairness and leadership, kind, and humble. The effective strategies for implementing character education include habituation, exemplary, direction, assignment, and environmental conditioning. However, there several factors and obstacles in the implementation of character education, including the school environment and infrastructure, knowledge and expertise of teachers, collaboration with other parties, support from parents.
\end{abstract}

Keywords: Character education, early childhood, Kindergarten

\section{Introduction}

Early childhood education is an effort aimed at facilitating the growth and development of children through adherence, guidance, and education. This helps them to be ready for further education, though not everyone understands. The low character quality is hazardous to the future of young people. Specifically, it hurts the formation of quality community resources and threatens the destiny of the nation. To form a good society, quality learning is needed, especially in terms of character education, which is inseparable from the role of teachers. A qualified educator is needed to achieve character education. In this case, the principal plays a significant role in controlling this kind of education in the institution. Teacher performance is significantly influenced by the role of the principal (Irawati et al., 2019). Generally, the principal, as the highest leader in the education unit, has a great responsibility and needs to show the integrity of personality and character (Metroyadi, 2016). Character building does not only depend on the management of the school organization but also the quality and strength of the principal (Suriansyah, 2015).

Character education can only be carried out well in case there is good cooperation between all aspects of education since success is determined by the foundation in learning and the elements in it, such as students, educators, student-teacher interaction, environment, material, and content (Salasiah et al., 2018).

In childhood, character formation needs to be achieved with full attention and seriousness to avoid regrets. The role of educational institutions is vital in providing moral guidance to children (Sudarna, 2014). The purpose of this research is to describe character values 
introduced and instilled in children, and education strategies in Gambah Luar Selatan Kindergarten and 'Aisyiyah 1 Islamic Kindergarten.

\section{Material and Methods}

This research uses a qualitative approach to understand behavior, perception, motivation, and action holistically. This is achieved through the description in the form of words and language, a special natural context, and utilizing various scientific methods (Moleong, 2007).

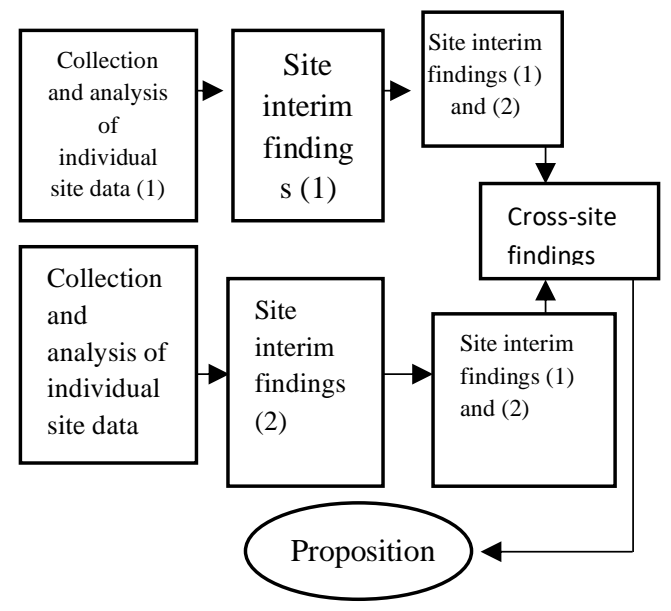

Figure 1. Cross-site data analysis
The research design is multi-site and focuses on the processes and elements related to the implementation of character. The primary source of information is educators with other people and documents as indirect and secondary data, respectively. The data collection techniques include observation, interview, and documentation. The following figure is a cross-site data analysis in this study.

\section{Results and Discussion}

This research was conducted at Gambah Luar Selatan Kindergarten and 'Aisyiyah 1 Islamic Kindergarten. Based on a letter from the Chairperson of the Master of Education Study Program for Early Childhood Teacher Education at Universitas Lambung Mangkurat Number: 122/UN8.4.9/PT.01.06/2019 September 16, 2019, data collection began at the Gambah Luar Selatan Kindergarten and 'Aisyiyah Bustanul Athfal 1 Kindergarten, Hulu Sungai Selatan Regency. The following is a comparison of data from Gambah Luar Selatan Kindergarten and 'Aisyiyah Bustanul Athfal 1 Kindergarten, Hulu Sungai Selatan Regency (Table 1).

Table 1. Comparison of Site Findings 1 and 2

\begin{tabular}{|c|c|c|c|}
\hline \multirow{2}{*}{ No. } & \multicolumn{3}{|c|}{ Comparison of Site Findings 1 and 2} \\
\hline & Research Focus & Site data 1 & Site data 2 \\
\hline 1 & $\begin{array}{l}\text { What are the character } \\
\text { values introduced and } \\
\text { instilled in children at } \\
\text { Gambah Luar Selatan } \\
\text { Kindergarten } \\
\text { 'Aisyiyah 1 and } \\
\text { Kindergarten? }\end{array}$ & $\begin{array}{l}\text { - Religious } \\
\text { - Honest } \\
\text { - Tolerance } \\
\text { - Discipline } \\
\text { - Hard work } \\
\text { - Creative } \\
\text { - Independent } \\
\text { - Democratic } \\
\text { - Curiosity } \\
\text { - Spirit of nationality } \\
\text { - Patriotism } \\
\text { - Appreciate Achievement } \\
\text { - Friendly / Communicative } \\
\text { - Love peace } \\
\text { - Like to read } \\
\text { - Environmental care } \\
\text { - Social care }\end{array}$ & $\begin{array}{l}\text { - Love God, the uni- } \\
\text { verse, and its contents } \\
\text { - Responsibility, disci- } \\
\text { pline, and independ- } \\
\text { ence } \\
\text { - Honesty } \\
\text { - Respect and courtesy } \\
\text { - Generous, Like to } \\
\text { - Help, and Cooperation } \\
\text { - Confident, Creative, } \\
\text { and Never Give Up } \\
\text { - Justice and leadership } \\
\text { - Good and humble } \\
\text { - Tolerance, Love of } \\
\text { Peace and Unity } \\
\text { To be continued... }\end{array}$ \\
\hline
\end{tabular}




\begin{tabular}{|c|c|c|c|}
\hline \multirow{2}{*}{ No. } & \multicolumn{3}{|c|}{ Comparison of Site Findings 1 and 2} \\
\hline & Research Focus & Site data 1 & Site data 2 \\
\hline & & - Responsible & \\
\hline 2 & $\begin{array}{l}\text { What strategy of early } \\
\text { childhood character } \\
\text { education is used in } \\
\text { Gambar Luar Selatan } \\
\text { Kindergarten and } \\
\text { 'Aisyiyah 1 Islamic } \\
\text { Kindergarten? }\end{array}$ & $\begin{array}{l}\text { - Habituation } \\
\text { - Exemplary } \\
\text { - Direction } \\
\text { - Assignment } \\
\text { - Environmental conditioning }\end{array}$ & $\begin{array}{l}\text { - Habituation } \\
\text { - Exemplary } \\
\text { - Direction } \\
\text { - Assignment } \\
\text { - Environmental } \\
\quad \text { tioning }\end{array}$ \\
\hline 3 & 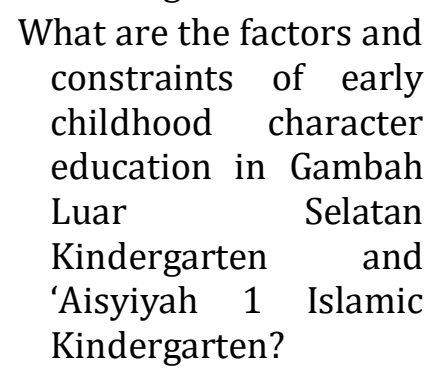 & $\begin{array}{l}\text { - Parents } \\
\text { - Educator's knowledge and ex- } \\
\text { pertise } \\
\text { - cooperation with outside par- } \\
\text { ties } \\
\text { - Environment and infrastruc- } \\
\text { ture condition of the child }\end{array}$ & $\begin{array}{l}\text { - Parents } \\
\text { - Educator's knowledge } \\
\text { and expertise } \\
\text { - cooperation with outside } \\
\text { parties } \\
\text { - Environment and infra- } \\
\text { structure condition of } \\
\text { the child }\end{array}$ \\
\hline
\end{tabular}

The character values introduced and instilled include religious and love of God, care for the environment/love of the universe and its contents, honest, tolerance, discipline, hard work or unyielding, creative, independent, Patriotism /love of peace and unity, responsibility, social care/philanthropic, helpful, and cooperation, democratic, curiosity, national spirit, respect for achievement, friendly and communicative, fond of reading, respectful and polite, confident, fairness and leadership, kind, and humble.

The two sites implement the values of character education in the activities of the institution. On-site 1, the source of values is guided by 18 character aspects from the Ministry of National Education. However, the source of character values in site 2 is guided by 9 characters pillars, though it is almost the same. It has the same goal of forming quality characters in students, since a strong personality is a fundamental foundation that defines the ability of the human population to live together and form a world filled with goodness and virtue, and free from violence and immoral acts (Hariyanto \& Samani, 2011).

Character values that are introduced and instilled in TK Gambah Luar Selatan refer to the Ministry of National Education version, which consists of 18 characters, namely religious, honest, tolerance, discipline, hard work, creative, independent, democratic, curiosity, national spirit, love of the motherland, appreciates achievements, is friendly, loves peace, likes to read, cares about the environment, cares socially and are responsible.

These character values as a reference in introducing and instilling character values in the souls of students that make everything whatever is done by students both activities in class and outside the class are always sought to be introduced and instilled character values to participants students and students are expected to be children who have these characters in daily behavior.

From the results of the study, it was found that at Gambah Luar Selatan Kindergarten implemented character education illustrated in the vision, mission, and goals at Gambah Luar Selatan Kindergarten. The curriculum used as a guideline is the 2013 curriculum which in applying its character values to be introduced and instilled in students refers to the character values of the Ministry of National Education numbering 18 characters, namely religious, honest, tolerance, discipline, hard work, creative, independent, democratic, curiosity, national spirit, love of the motherland, appreciates achievements, is friendly, loves peace, likes to read, cares about the environment, cares socially and responsibility. 
These character values are introduced and instilled in students to foster good qualities and habits in students.

From the results of research in Kindergarten 'Aisyiyah Bustanul Athfal 1 it is known that in Kindergarten 'Aisyiyah Bustanul Athfal 1 implements character education that is reflected in the vision, mission, and objectives in Kindergarten 'Aisyiyah Bustanul Athfal 1. The curriculum used as a guideline is the 2013 curriculum which is in the application of the curriculum the character values to be introduced and instilled in students refer to the 9 character pillars of the IHF version (Indonesia Heritage Foundation), namely: (1) Love of God and the universe and its contents, (2) Responsibility, discipline, and independence, (3) Honesty, (4) Respect and Courtesy, (5) Generous, Loving and Collaborative, (6) Self-Confidence, Creative, and Unyielding, (7) Justice and Leadership, (8) Good and Humanity, (9) Tolerance, Love of Peace and Unity. These values are introduced and instilled in students to foster and develop moral behavior in daily life.

The character education strategies at both sites have a common strategy, including habituation, exemplary, direction, assignment, and environmental conditioning. Habituation in character education strategies to introduce and instill character values in their students. Students are accustomed to shaking hands or commonly referred to as "Salim" when children come to school and come home from school so that this activity is intentionally introduced and instilled character values in the souls of students. So that students are accustomed to being religious and respectful towards the teacher or a more mature person. This activity is carried out continuously every day so that students are accustomed to doing it in everyday life.

The habituation method applied is quite effective in training students to practice good things. The school activities are always adjusted to the following rules for the children to be accustomed to doing the right things in their daily lives. In addition to habituation, exemplary is also applied as a strategy in the implementation of character education in Gambah Luar Selatan Kindergarten, this was said by the Kindergarten Principal during the interview saying that teachers give examples to students every day because children in kindergarten imitate or imitate from what his teacher's mother did. Role models are very effective for fostering student character in school. Exemplary in schools played by the principal, teachers, and school employees.

The exemplary role is carried out by all teachers, employees, and anyone in the school environment, including parents. All components or the school community, including parents, carry out character education, therefore becoming a real example for all students (Cinantya et al., 2018). This method is very effective in early childhood since new character education hit the target in case it is exemplified, not taught. Good behavior practiced by teachers in front of their students is often emulated; hence, they form habits. This means that the teacher needs to have a strong character for students to imitate (Aziz, 2012).

Every activity starts with a teacher's direction applied in education. It allows students to understand the philosophical values of what they learn. The assignment is also an effective way of recognizing and instilling character values in early childhood. Apart from assigning tasks to children, parents need to also take part in them. This is practiced in "Gambah Luar Selatan Kindergarten and 'Aisyiyah 1 Islamic Kindergarten "in socializing the importance of the role of parents participating in providing education at home, especially character education. The goal is to ensure recognition and instilling of character values in children is consistent and continuous. This makes them stronger and more inherent until they are adults.

A good school environment is also effective in supporting the implementation of character education. All school members provide examples that reflect good character values. The environment gives a stake in the formation of one's attitude and behavior, both based on the natural and the social environment (Zubaedi, 2005). In fostering the character of one of them with environmental conditioning, the atmosphere of the school is conditioned in such a way by providing physical facilities. As in the Gambah Luar Selatan Kindergarten that 
provides rubbish bins so that children and other school residents dispose of trash in their place, the bins are strategically placed to make it easy to dispose of rubbish. This can get children accustomed to caring about their enviroment and taking responsibility for their food waste.

There are several factors and constraints in the implementation of character education on sites 1 and 2, including the school environment and infrastructure, knowledge and expertise of teachers, collaboration with outside parties, support from parents, and the child's condition. Moreover, the factors that influence the implementation of the curriculum include teachers, parents, students, environment, and government (Afifah et al., 2019).

God entrusts children to parents; hence, they have the responsibility of looking after them actively. They need to make an effort since this is the most appropriate way of providing education (Aziz, 2013). Responsibilities need to be based and fostered by parents towards children, including (1) Nurturing and raising them, since they need to eat, drink and care to live sustainably,(2) Protect and guarantee health, both physically and spiritually from various diseases or environmental hazards that could endanger lives,(3) Educating with various sciences and skills useful for their own lives, helping others (hablum minannas) and carrying out their caliphate, and (4) Making children happy for the world and the hereafter by giving them religious education in line with God's provisions as the ultimate goal of Muslim life (Arifin, 2005).

Parents who are less supportive of their children's education become obstacles. For example, they are less supportive of school activities by not participating in programs held, yet education is a shared responsibility. In case parents take an active role in children's education, especially character education, the introduction and instilling of character values might be more effective. This involves active communication with educators on the development of children in school. In general, communication is stated as the core of life in organizations, helping them to develop optimally; communication is a key to successful team effort (Suriansyah, 2014).

Environmental factors are also critical in the process of introducing and instilling character values in students. It is one aspect that is quite essential in the formation of one's attitude and behavior based on the natural and the social environment (Zubaedi, 2005).

One of the essential components of education is the teacher. Their role in implementing character education is not only limited to teaching and delivering material but also plays an active role in every word and behavior. This is because their attitude and nature serve as examples for their students. To be a good educator, there is a need to have knowledge and insight, which can be acquired by attending seminars or training in early childhood education. Since character education emphasizes aspects of the attitudes, values, and character of students, it needs to start from the teacher first. (Mulyasa, 2013).

Site 1 uses the library, where teachers accompany children to visit the library and also collaborate with "rocket chicken" restaurants, which usually hold coloring competitions and make burgers to enrich the experience of students and introduce character values such as like to read and appreciate achievement. The teachers also collaborated with the "smart home" studio for dance practice aimed at increasing their skills at "Gambah Luar Selatan Kindergarten." 'Aisyiyah 1 Islamic Kindergarten in collaborated with the Indonesia Heritage Foundation (IHF) to educate children in the national character. This move is intended to add experience and insight, which form good character.

Children coming to school in a healthy condition are easily follow learning activities. Conversely, those who come to school in an unhealthy state find it difficult to learn. This affects children's emotions, and therefore, this becomes an obstacle in the implementation of character education. The quality of education has been determined mainly by the student's character. Therefore, the focus on character development needs to be prioritized (Sukriani et al., 2017). Children's emotions influence and become obstacles in the process of character 
education. Especially for new students or early school activities after a long holiday. But this school is a child-friendly school, meaning that the school gives freedom to students if they are still not accustomed to doing activities following the habits at school. The goal is to make children feel comfortable first. When children feel comfortable, then they can slowly do learning activities following school activities. Unhealthy children also become obstacles in the implementation of character education, because unhealthy bodies make children less enthusiastic in participating in school activities, so it becomes an obstacle also in the introduction and inculcation of character values.

From the results of research at TK Gambah Luar Selatan about the factors and constraints of character education, it was found that the success factors in character education include parental support, educator's knowledge, and expertise, collaboration with outsiders, the environment and infrastructure. While the obstacles faced in the implementation of character education include less supportive parents and the child's condition.

Based on observations, interviews, and documentation of researchers, the character values introduced and instilled in early childhood at site 1 are guided by 18 elements formulated by the Ministry of National Education, such as religious, honest, tolerance, discipline, hard work, creative, independent, democratic, curiosity, national spirit, Patriotism, respect for achievement, friendly/communicative, peace-loving, fond of reading, environment, and social caring, and responsibility. Character education strategy on-site 1 includes habituation, exemplary, direction, assignment, and environmental conditioning. The strategy is implemented by educators to introduce and instill character values in students. Factors that support the success of character education on-site 1 include parental support, school environment and infrastructure, knowledge and expertise of teachers, and collaboration with outside parties. Less supportive parents and the condition of the child are the significant constraints in the implementation of character education. Parents have an active responsibility for children. Paying attention and supporting their children's education has a significant influence on their education. Parental care patterns affect children's social behavior (Putri et al., 2019). In contrast, less supportive parents are likely to be obstacles in children's character education. The school environment and infrastructure are essential factors in education due to their significant influence on character building.

Knowledge and expertise of educators is a determinant of the success of character education, ensuring teaching is carried out correctly and according to the needs of students. Collaboration with the library and "rocket chicken" restaurant by the institution on-site 1 indirectly boosts learning and gives an additional experience for educators and students. Character values are introduced and instilled in students based on 9 pillars formulated by the IHF, including the love of God, the universe and its contents, responsibility, discipline and independence, honesty, respect, and courtesy, generous, helpful, and cooperation, confident, creative, and unyielding, justice and leadership, kind and humble, tolerance, peace and unity.

Character education strategies include habituation, exemplary attitude, direction, assignment, and environmental conditioning. The strategy is implemented by educators to students to introduce and instill character values. Educators encourage children to shake hands and say hello, pray before and after activities and speak politely. Besides asking children to get used to good deeds every day, educators also provide exemplary attitudes, because children are very easy to imitate what others do. The briefing is conducted every time an activity is carried out. Therefore children not only participate in the activity but also understand why they have to take part in them. Teacher's directions ensure the activities run in an orderly manner since children are prepared in advance. Assignments are given to students as part of their responsibilities. Additionally, tasks are also given to parents to ensure there is continuity between character education in schools and education in their families. The environmental conditions designed in Islamic have a positive impact on anyone who sees and 
feels them. Everyone is encouraged to act according to Islamic behavior.

Factors that support the success of character education on sites 1 and 2 include parent support, school environment, and infrastructure, knowledge and expertise of teachers, collaboration with outside parties. Constraints in the implementation of character education include less supportive parents and the condition of the child.

\section{Conclusion and Recommendation}

Character values introduced and instilled in early childhood include religious and love of God, care for the environment or the universe and its contents, honest, tolerance, discipline, hard work / unyielding, creative, independent, patriotism/love of peace and unity, responsibility, social care / philanthropic, helpful, and cooperation, democratic, curiosity, national spirit, respect for achievement, friendly and communicative, fond of reading, respectful and polite, confident, fairness and leadership, kind and humble.

Character education strategies used include habituation, exemplary attitude, direction, assignment, and environmental conditioning. In general, several factors and obstacles in the implementation of character education include the school environment and infrastructure, knowledge and expertise of teachers, collaboration with other parties, support from parents, and the child's condition. The principals need to develop parenting activities and create special programs for joint activities between parents and children, especially in terms of character education. It should be more active in communicating with parents, especially about children's character education. Holding parenting activities with face-to-face meetings, parenting activities can be conducted by creating special social media for the benefit of children's character education. For instance, creating a character parenting group in WhatsApp might be helpful.

Educators need to participate in children's activities at school. They should provide examples of real behavior for students, especially in the process of implementing character education, such as playing. Teachers participate in such activities always introduce and instill character values in every opportunity. Parents should participate in children's education. Active communicating with teachers at school helps them understand the child's development from time to time. They also need to support learning programs in schools to optimize children's education.

\section{Acknowledgment}

Our gratitude and appreciation extend to all parties involved and contributed in completing this research.

\section{References}

Afifah, Aslamiah, \&Suriansyah, A. (2019). Implementasi of islamic aqeedah based curriculum. Jounal of K6, Education and Management, 2(1), 41-47.

Arifin, M. (2005). Filsafat pendidikan islam (edisi revisi). Jakarta: Bumi Aksara.

Aziz, A. A. (2012). Guru profesional berkarakter. Klaten: Cempaka Putih.

Aziz, A. A. (2013). Meletakkan fondasi emas anak indonesia (pola pembelajaran PAUD berkarakter). Klaten: Cempaka putih.

Cinantya, C., Asniwati, \& Suriansyah, A. (2018). The model of religion-based character education (multi-site integrated islamic PAUD Sabilal Muhtadin and PAUD Islam Mawaddah Banjarmasin, Indonesia). European Journal of Education Studies, 5(7), 1-13.

Hariyanto, \&Samani, M. (2011). Konsep dan model pendidikan karakter. Bandung: Remaja Rosda Karya.

Irawati, A., Aslamiah, \& Saleh, M. (2019). Relationship between principal role, work motivation and job satisfaction with elementary school teacher performance. Journal of $\mathrm{K} 6$, Education and Management, 2(2), 87-96.

Metroyadi. (2016). Kepemimpinan pendidikan berbasis karakter dalam mengimplementasikan manajemen berbasis sekolah. (pp. 2(1), 23-28). Banjarmasin: Prosiding Seminar Nasional PS2DMP UNLAM.

Moleong, L.J. (2007). Metodologi penelitian kualitatif. Bandung: Remaja Rosda Karya.

Mulyasa, E. (2013). Menjadi guru profesional . Bandung: Remaja Rosda Karya.

Putri, H., Suriansyah, A., \&. Wahdini, E. (2019). Effect of education income levels and parenting patterns on children's social behavior. Journal of K6, Education and management, 2(2), 97-106.

Salasiah, Asniwati, \& Effendi, R. (2018). Instilling character values in early childhood in the perspective of curriculum and parenting (multi-site study in PAUD Islam Sabilal 
Muhtadin and PAUD Mawaddah, Banjarmasin, Indonesia. European Journal of Education Studies, 5(7), 36-48.

Sudarna. (2014). PAUD berkarakter. Yogyakarta: Genius publisher.

Sukriani, Huda, A.Y. M., Arifin, I., \& Suriansyah. (2017). The implementation of the islamic schools resources total quality management in Banjarmasin, Indonesia. Journal of Social Sciences (COES\&RJ-JSS), 6(1), 125-138.
Suriansyah, A. (2014). Hubungan budaya sekolah, komunikasi, dan komitmen kerja terhadap kinerja guru sekolah dasar negeri. Jurnal Cakrawala Pendidikan, 3, 358-367.

Suriansyah, A. (2015). Strategi kepemimpinan kepala sekolah, guru, orangtua dan masyarakat dalam membentuk karakter siswa. Jurnal Cakrawala Pendidikan, 2(2), 234247.

Zubaedi. (2005). Tahapan mendidik anak. Bandung: Irsyad Baitus Salam. 